after the expiry of the period of 4 clear weeks in this paragraph referred to.

\section{Honorary Officers}

Fellows and Members of the College are reminded of their rights in connection with the forthcoming elections for the offices of Dean, Registrar, Treasurer, Editor and Librarian. All Honorary Officers are eligible for re-election, although the Librarian, Dr lan Pullen, does not wish to be re-elected.

The nominating meeting of Council will take place on 23 April 2001 and the last date for receiving nominations will therefore be 21 May 2001. The relevant Bye-Laws and Regulations are printed below.

\section{Extracts from the Bye- Laws and Regulations}

\section{Bye-Law XII The Other Honorary} Officers

1. The Council shall, in accordance with the Regulations, make its nominations for the offices of Dean, Registrar, Treasurer, Editor and Librarian at the first meeting after the name of the President for the next ensuing College year has become known. Written nominations for the above Honorary Offices, accompanied in each case by the nominee's written consent to stand for election, may also be lodged with the Registrar at such time as may be prescribed by the Regulations, provided that each such nomination is supported in writing by not less than 12 Members of the College who are not members of the Council.

2. The Dean, Registrar, Treasurer, Editor and Librarian shall be elected from among the Fellows, by the Members of the College, in each case in accordance with the procedure prescribed by the Regulations.

\section{Regulation XII Election of the Other Honorary Officers}

1. The method of electing the Honorary Officers other than the President, the Vice-Presidents, Sub-Deans and Deputy Registrars shall be the same as that for electing the President, save that nominations from Members of the College who are not members of the Council shall be lodged with the Registrar between the first day of June in any calendar year and the date which is 4 clear weeks after that meeting of the Council which is the first held after the name of the President for the next ensuing College year has become known.

\section{Extract from College Regulations}

Membership under

Bye-Law III 2(ii) categories (a), (b) and (c)

The Royal College of Psychiatrists has recently been given leave by the Privy Council to extend this Bye-Law, and is now able to offer Membership without Examination to the following three groups of doctors:

(a) medical graduates of exceptional distinction - up to a limit of eight per College year and 100 in all at any one time;

(b) qualified medical practitioners who qualify in the European Economic Area (EEA) and who are on the specialist register of the General Medical Council or the Medical Council of Ireland and who are in specified grades prescribed by the Regulations;

(c) qualified medical practitioners who qualify outside the EEA and who are on the Specialist Register of the General Medical Council or the Medical Council of Ireland and who are in specified grades prescribed by the Regulations.

To nominate an individual under this Bye-Law please contact Dr Anne Dean in the Department of Postgraduate Educational Services, The Royal College of Psychiatrists, 17 Belgrave Square, London SW1X 8PG, and the relevant forms will be forwarded to you. The closing date is 30 September 2001.

\title{
obituaries
}

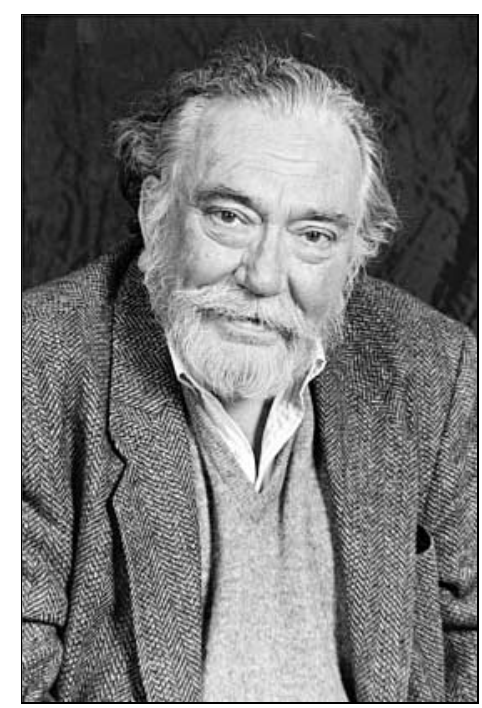

\section{George Frederic Spaul}

Formerly Consultant Psychiatrist, Towers Hospital, Leicester

George Spaul was born in London on 5 March 1925. Having attended Willesden County School he obtained the Bucknill
Scholarship and proceeded to University College Hospital from 1943-1948, part of the time being spent in Leatherhead, to where the hospital had been evacuated. The scholarship was very significant, as Dr Bucknill, the originator of the scholarship, was a very distinguished psychiatrist.

He qualified MB, BS (Lond) in 1948 and his first house officer post was at the Towers Hospital, Leicester, starting on the 'appointed day' - when the NHS was first started.

He did his National Service in the Royal Army Medical Corps, becoming a junior specialist in psychiatry, and entered his formal psychiatric career as registrar at Shenley Hospital. He became a senior registrar at Belmont Hospital in 1954 where he came under the influence of Dr Maxwell Jones, his Unit at Belmont being the progenitor of the Henderson Hospital. This was George's first contact with the concept of the therapeutic community. He then attended the Tavistock Clinic course in group therapy.

He became a senior house medical officer at the Coppice Hospital, Nottingham, working with Dr Keith Woddis, and had further experience of group therapeutic techniques. In 1965 he was appointed at the Towers Hospital as a consultant and remained in the Leicester area for the rest of his professional career, retiring in 1987.

I had the good fortune to join him at the Towers in 1967 and worked with him in a true partnership up to his retirement. He embarked on setting up the Francis Dixon Lodge (FDL), a therapeutic community in the grounds of the Towers, which is still very active and is a proper tribute to his foresight and clinical acumen. He undertook lecturing and group work for the Midland course in group work and family therapy, as well as being the consultant for the Samaritans, Cruse and the Marriage Guidance Council. He continued work at the FDL until 1992, on a part-time basis after his retirement from general psychiatry.

George was a founder Member of the Royal College of Psychiatrists in 1971 and then became a Fellow in 1980. He was a very competent and most caring psychiatrist with whom it was a pleasure to work. His patients could always rely on his integrity, knowledge and compassion in dealing with their problems. 